\title{
Mining for a week or for centuries: Variable aims of flint extraction sites in the Mons Basin (Province of Hainaut, Belgium) within the lithic economy of the Neolithic
}

\author{
Jean-Philippe Collin \\ Université de Namur, Département d'Histoire de l'Art et Archéologie, Rue de Bruxelles n61, B-5000 Namur, \\ Belgium. Email: collin.jeanphilippe@gmail.com
}

\begin{abstract}
:
The Mons Basin (Province of Hainaut, western Belgium) is a geologically rich region, particularly from the point of view of Upper Cretaceous sedimentary deposits, conducive to an important flint gathering activity during the whole regional Prehistory. Focusing on the Neolithic period, indications of flint procurement as early as the end of the 6th millennium have been recorded, but there are concrete evidences of mining sites in the region since the second half of the 5th millennium. Flint extraction activities have lasted at least until the second half of the 3rd millennium. According to literature and recent researches, eleven sites could be extraction sites, including the World Heritage site of Spiennes. This paper critically assesses the accuracy of the data available and focuses on the issue of the unequal function of these extraction sites and their socio-economic function for Neolithic communities. Is it really possible to establish a hierarchy between the extraction sites? Can different acquisition-production strategies be highlighted? These questions are dealt with by synthesizing the data concerning the methods of flint exploitation in the Mons Basin, the qualitative and quantitative characteristics of the products relative to the production intentions but also by addressing the issue of their importance in exchange networks.
\end{abstract}

Keywords: Neolithic; flint mines; flint acquisition strategy; socio-economic function; Mons Basin

\section{Résumé:}

Le Bassin de Mons (Province de Hainaut, ouest de la Belgique) est une région géologiquement riche, particulièrement en ce qui concerne les dépôts sédimentaires du Crétacé Supérieur, propice à une importante activité d'acquisition de silex durant toute la Préhistoire régionale. Concernant le Néolithique, bien que des indices d'acquisition du silex soient connus dès la fin du $6^{\mathrm{e}}$ millénaire, c'est à partir de la seconde moitié du $5^{\mathrm{e}}$ millénaire que se développent les sites miniers. Une importante activité d'extraction du silex a duré au moins jusqu'à la seconde moitié du $3^{\mathrm{e}}$ millénaire. Selon la littérature et des recherches récentes, onze sites pourraient être des sites d'extraction, dont le site Patrimoine Mondial de Spiennes. Cet article se penche sur la pertinence des données disponibles et se concentre sur la problématique des statuts inégaux de ces sites d'extraction et leur implication socioéconomique pour les communautés néolithiques. Est-il réellement possible d'établir une hiérarchie entre les sites d'extractions? Différentes stratégies d'acquisition-production peuvent-elles être mis en

Published by the School of History, Classics and Archaeology, University of Edinburgh ISSN: 2055-0472. URL: http://journals.ed.ac.uk/lithicstudies/

This work is licensed under a Creative Commons Attribution 2.5 UK: Scotland License. 
exergue? Ces questions sont traitées en synthétisant les données concernant les méthodes d'exploitation du silex au sein du Bassin de Mons, les caractéristiques qualitatives et quantitatives des produits des produits, mais aussi en abordant la question de leur importance dans les réseaux d'échange.

Mots-clefs: Néolithique, mines de silex, stratégie d’acquisition de silex, fonction socio-économique

\section{Introduction}

While flint raw materials in the Mons Basin were exploited throughout prehistory, the earliest evidence for recurrent extraction dates to the earliest phases of the Belgian Neolithic (5200-4900 BCE). The first farming and pastoral populations of Western Belgium, belonging to the Linear Pottery Culture and subsequently to the Blicquy and Villeneuve-Saint-Germain Culture, settled during the last quarter of the 6th millennium in an area approximately $10 \mathrm{~km}$ north of the basin where the river Dendre has its two sources (Constantin 1985). These populations mainly used a type of flint known as "Ghlin" flint, which is thought to originate in the basin (Denis 2014; Hubert 1970). The majority of the artefacts within assemblages exhibits cortex and cores which are very little altered, a fact which would indicate that the raw material was acquired in a primary context. To date, however, no extraction site linked to the earliest neolithisation has been identified in the Mons Basin (see section 5.3.2). During the second half of the $5^{\text {th }}$ millennium, communities belonging to the Michelsberg culture in the Mons Basin made thousands of shafts-sinking works, several metres in depth into the ground surface in order to exploit seams of flint. The most spectacular evidence for this transformation in raw material acquisition strategy is, without question, the development of the Spiennes site (which today lies within the Mons Municipality). It was exploited from the Middle Neolithic (Michelsberg Culture, 4300-3600 BCE), through the Late Neolithic (SeineOise-Marne culture, 3600-3000 BCE) and into the Final Neolithic (Deûle-Escaut Group, 3000-2300 BCE) (Collet et al. 2008a). This exceptional longevity for a raw material extraction site (almost two millennia!) prompts us to reconsider the importance of the Mons Basin extraction sites and the role that they each played in the economy of Neolithic populations.

\section{Issues involved}

The questions addressed in this paper are part of a doctoral thesis financed by the Fund for Scientific Research (F.R.S.-F.N.R.S.) within the Universities of Namur and Paris 1 Panthéon-Sorbonne. On the one hand, this research aims to identify and characterise the variability of extraction sites and their products within the lithic economy, from their initial development in the $5^{\text {th }}$ millennium to their decline at the end of the $3^{\text {rd }}$ millennium BCE, from a local, regional and extra-regional perspective. On the other hand, it seeks to define the modalities of product diffusion and identify a possible production strategy for mining sites at the scale of the Mons Basin (the possibility of a form of organisation between mining sites cannot be excluded). In the longer term, the entire chaine opératoire is being considered: the methods of extraction (Collin 2010; Collin \& Collet 2011), the products (Collet et al. 2014) and their diffusion (Bostyn et al. 2011), transformation, recycling and eventual abandonment. This data will allow the relationships between mines and settlements, as well as the role of the mining sites in the structuring of territory, to be defined (de Labriffe \& Thirault 2012; Pelegrin \& Richard 1995).

Within the Mons Basin, eleven Neolithic flint mines are cited in the literature. Should all of these sites be referred to as mining sites? In addition to their size and the varying duration 
of their occupation, these sites are also characterised by the extraction methods employed, their products and the diffusion of these products. What do the differences between them signify and imply? Do they reflect differences in the status of the extraction sites? In other words, do they represent different functions within the socio-economic organisation of Neolithic populations?

\section{Method and corpus}

It is not possible to tackle the issue of the status and functional role of each extraction site within the Mons Basin, and, secondly, to illustrate the circulation of the products, without first making concrete progress regarding the identification of the raw materials present within the Basin. To this end, we initially based our approach on the lithic collection of The Royal Belgian Institute for Natural Sciences (IRSNB), and in particular on the collection begun in 2012 by the informal work group "Mons Basin lithotheque". Within the framework of the latter, the partners, under the guidance of researchers from The Society for Prehistoric Research in Hainaut (SRPH) and from the Wallonia Public Service (SPW), aim to document flint resources present in the Basin (Collin \& Collet 2012). The data provided by these collections are completed with the help of survey work carried out in modern quarries, in areas of flint outcrops and on confirmed or proposed extraction sites. Macro- and mesoscopic examination of geological and archaeological samples from extraction sites has allowed the identifications of characteristic elements, while laser-induced breakdown spectroscopy (LIBS) has led to a better understanding of the contexts and formation processes of flints in the Mons Basin (Collin \& Baele 2016) (for additional data on flint sourcing in the Mons Basin by laser ablation inductively coupled plasma mass spectrometry (LA-ICP-MS), see Moreau et al. (2016)).

The archaeological material under consideration here derives from collections of the SPW (Spiennes, Harmignies), the SRPH (Spiennes, Mesvin), the IRSNB (Flénu, Douvrain, Obourg) and from bodies of material collected by surveyors, Jean Dufrasnes and Michel Van Assche (Villerot) (quantitative details will be outlined in detail within the thesis).

\section{Context: The Mons Basin}

The Mons Basin is named after a town in western Belgium, capital of the province of Hainaut. It is an annexe of the Paris Basin that covers approximately $480 \mathrm{~km}^{2}$ and which more or less coincides with the present day valley of the River Haine.

The formation of the basin is linked to a phenomenon of subsidence, which began at least 100 million years ago. It was caused by tectonic activity (transtensional basin) or by the dissolution of anhydrite strata several hundreds of metres thick at a depth of over 2000 metres. The direct consequence of this subsidence is the formation of a geology characterised by the accumulation of Cretaceous and Tertiary layers over a thickness of approximately 300 m (Mortier 2012: 62-63). The richness of the Cretaceous substrate makes it one of the three areas of flint extraction sites of Belgium, the two other being located in the valley of the Lower Meuse. The basin, which extends from east to west, includes flint-bearing chalk deposits that were formed during the Campanian, Turonian and Coniacian-Santonian stages. It appears that only flints from Campanian and Turonian chalks were mined and this exploitation was confined to the slopes in the middle part of the basin, an area of less than 75 $\mathrm{km}^{2}$.

Since the overview of Belgian mining sites published by François Hubert in the Bochum catalogue (Weisgerber et al. 1980), research has continued at Spiennes (Collet et al. 2016), the mining status of the Flénu site has been confirmed (Leblois 2000) and the presence of new extraction sites at Villerot (Van Assche \& Dufrasnes 2009) and Harmignies (Collet et al. 
2004) has been postulated. The status of the Obourg sites remains uncertain (Jadin et al. 2008). According to the literature, and on the basis of recent advances, eleven mining sites have been identified within the Mons Basin: Villerot, Douvrain, Ghlin, Obourg and Strepy on the northern slopes; Flénu, Ciply, Mesvin, Spiennes, Harmignies and Saint-Symphorien to the south. Our own research has produced new elements and, therefore, before addressing the issue of the unequal status of extraction sites, it is pertinent to critically assess the accuracy of the data available in the literature as summarized in Table 1.

Table 1. Critical analysis of extraction sites in the Mons Basin. The three areas of Spiennes are considered as parts of a single site isolated by natural element such as the La Trouille valley. Abbreviations: U - elements that are mentioned in literature but which are unverifiable.

\begin{tabular}{|c|c|c|c|c|c|c|c|c|c|}
\hline \multirow[b]{2}{*}{$\begin{array}{l}\text { Site } \\
\text { Locality }\end{array}$} & \multirow[b]{2}{*}{ Area } & \multicolumn{4}{|c|}{ Elements of authenticity } & \multicolumn{4}{|c|}{ Status } \\
\hline & & 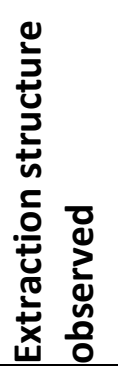 & 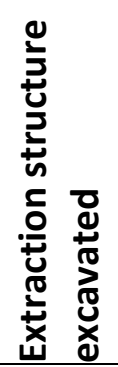 & 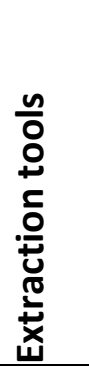 & 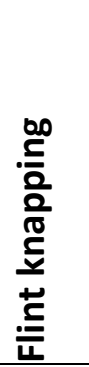 & 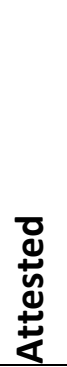 & $\begin{array}{l}\frac{0}{0} \\
\frac{0}{\pi} \\
\frac{0}{0} \\
\frac{0}{2}\end{array}$ & 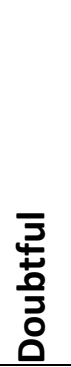 & 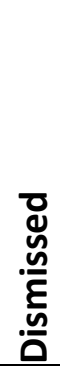 \\
\hline Baudour-Douvrain & Temple et 3 champs & No & No & Yes & Yes & & $x$ & & \\
\hline Ciply & Trous des Sarrasins & $U$ & No & Yes & Yes & & & $x$ & \\
\hline Flénu & L'Ostenne & Yes & No & Yes & Yes & $x$ & & & \\
\hline Ghlin & Le Moulineau & No & No & No & Yes & & & & $x$ \\
\hline Harmignies & La Fosse & Yes & Yes & Yes & Yes & $x$ & & & \\
\hline Mesvin & Sans-Pareil & Yes & Yes & Yes & Yes & $x$ & & & \\
\hline \multirow[t]{2}{*}{ Obourg } & Le Village & $U$ & No & Yes & $U$ & & & $x$ & \\
\hline & Carrière Denuit & No & No & No & No & & & & $x$ \\
\hline Saint-Symphorien & $\begin{array}{l}\text { Le Cerneau et } \\
\text { Phosphates }\end{array}$ & No & No & No & Yes & & & & $x$ \\
\hline \multirow[t]{3}{*}{ Spiennes } & Camp-Cayaux & Yes & Yes & Yes & Yes & $x$ & & & \\
\hline & Petit-spiennes & Yes & Yes & Yes & Yes & $x$ & & & \\
\hline & Versant de la Wampe & Yes & Yes & Yes & Yes & $x$ & & & \\
\hline Strepy & Carrière Roland & No & No & No & No & & & & $x$ \\
\hline Villerot & Lambiez & No & No & $U$ & Yes & & $x$ & & \\
\hline
\end{tabular}

The selected distinguishing characteristics are based on those used for mining sites in the Oise and Somme in the PCR publication "Géoarchéologie du silex du Nord-Ouest de la France" (Allard et al. 2005: 71). These criteria aim to highlight the extraction activity on the one hand (field observation, excavation, discovery of extraction tools made of flint or red deer antler), and the products on the other (chipping floor). Additional evidence such as localised surface clusters of chalk lumps and the presence of concentric depressions (both of which are indicators of the presence of an extraction pit) have ultimately been rejected. In fact, these features can result from the digging of test pits associated with the phosphate chalk industry, which operated in the late $19^{\text {th }}$ and early $20^{\text {th }}$ centuries.

The Trous des Sarassins area in Ciply has been destroyed by activity related to the ceramic and phosphate chalk industries (Cornet 1947: 45; Gosseries 1908: 30). At the Le Moulineau site in Ghlin, the discovery of artefacts of Turonian flint, which is abundant in the area, can in no way be taken to indicate the presence of an extraction site (Weisgerber 1980: 
432). The skeletons of miners, supposedly killed in an accident, from the Roland Quarry in Strépy and from the Denuit Quarry in Obourg are a hoax (de Heinzelin et al. 1993). At Le Village in Obourg, antler tools dated to $4690-4450$ cal. BCE $(2 \sigma)$ could be the oldest flint extraction tools known in North-western Europe, but the site did not yield any associated lithic material or any evidence of extraction structure (Jadin et al. 2008). The discovery during roadworks of further antler tools and a back-filled shaft remains unverifiable (Hubert \& Lefrancq 1973: 57). In the case of the Le Cerneau-Les Phosphates site at SaintSymphorien, it has not been possible to identify a siliceous deposit that could be used for tool production. Our surveys of the area suggest that the flints used for artefacts present in the area are exogenous in nature and that the "red" colour of the flints cited in the literature (Munck 1928; 1929) is due to an epigenetic process. These sites will not, therefore, be considered further in this study.

\section{Characterising the extraction sites}

From our initial corpus of sites, six extraction sites have been retained for further study: Villerot and Douvrain in the northern part of the basin; Flénu, Mesvin, Spiennes and Harmignies to the south. These sites can be differentiated on the basis of the methods used to extract the raw material, the various products produced, and, according to our preliminary results, their relative importance within raw material distribution networks. (See Figure 1.)

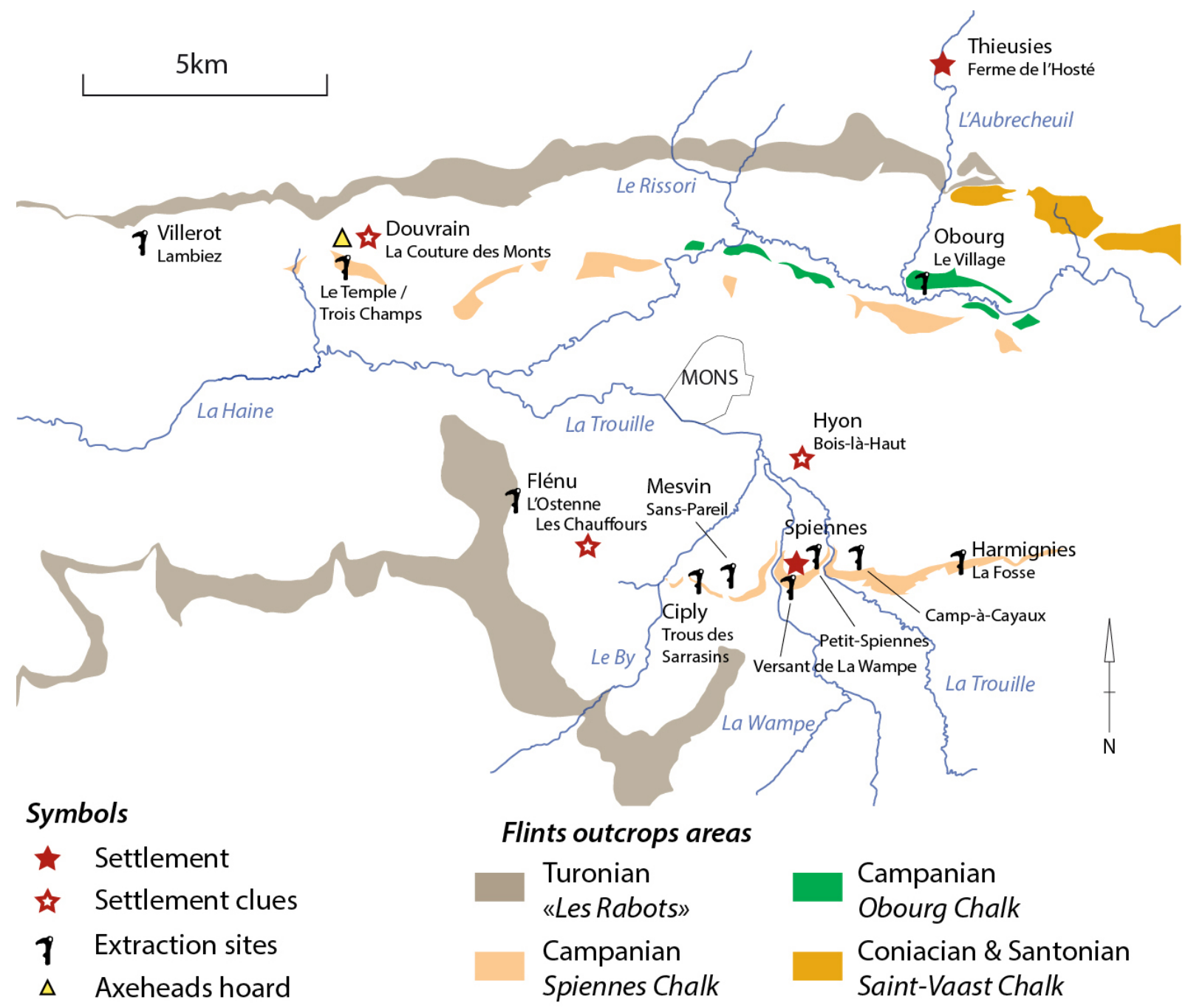

Figure 1. Extraction sites and settlements in the Mons Basin (Modified after Collet 2014). 


\subsection{Parameters studied}

\subsubsection{Extraction methods}

In contrast to the deep underground mines (Spiennes, Flénu), the exploitation of surface flint within dissolution pipes (Harmignies, Villerot) or primary position outcrops on valley slopes (possibly Villerot) represents a lesser investment. The exploitation of dissolution pipes must have been accompanied by rigorous sorting of the weathered raw material. This modus operandi must have restricted the possibilities in terms of production range (acquisition of a block with adequate morphometry), as well as their scale. Exploitation on valley slopes allows quick access to raw material in a primary position but, as was the case with the exploitation of dissolution pipes, this procedure would have been difficult to reproduce in an exclusive manner over a large area.

Extraction involving deep shafts and pits for the exploitation of flints in a primary position are probably the logical result of exploitation on the valley sides. They constitute models that are reproducible over a large area, guaranteeing access to flint raw materials which are unaltered or little altered. Their depth is a function of the depth of the seams of flint. Different methods may have been used within the same site (workings on the valley slopes and in pits are both found at Spiennes). The methods used are determined by the gitology, the scale and the nature of the products envisaged.

\subsubsection{The products}

The productions carried out on the extraction sites act as the pivot around which extraction and distribution revolve. On the one hand, the products resulting from the transformation of the raw material in part determine the acquisition strategy for that raw material (mass production of blades and axeheads, for example, cannot be based on the gathering of flint from rivers), while on the other hand, the nature of the products and the quality of their execution directly influence their valorisation within the distribution networks. How can these two parameters be quantified? The mining context does not constitute a guarantee of the quality of product execution: apprentices operated within knapping workshops just as experienced knappers worked in domestic contexts. It is, therefore, important to be able to dissociate the production context- even though it can itself be considered specialised because it is separate from the domestic milieu- and the know-how of the producer. However, it is impossible to precisely define the latter within the framework of activity carried out at the scale of several extraction sites. As a result we have to base our observations on the principal products from each site so as to obtain an overall picture of the level of expertise. The various types of production are henceforth defined as follows:

- Non-framed: describes the manufacture of non-standardised tools using simple techniques (e.g., non-predetermined débitage);

- Framed: describes predetermined production of standardised items which result from the systemised application of an elaborate modus operandi requiring specific know-how (e.g., regular bifacial manufacture, predetermined blade débitage) ("framed" is a translation of the french word "normalisé" (see, for example, Allard et al. 2006);

- Specialised: describes a framed product of exceptional workmanship that requires the application of specific, complex modi operandi requiring a high level of technicity (e.g., Pressignian long blades).

These three categories are defined by the qualitative and quantitative characteristics of the products relative to the production intentions (Pelegrin 1991). It is important to note that the notions of specialised and specialist production only partly overlap. For example, individuals who manufactured framed products which lie outside the consumption pattern of 
their community can be considered as specialists (Pelegrin 2007). Within Neolithic mining workshops, knappers who manufactured products such as standardised axeheads ought to be considered as specialists.

\subsubsection{Product distribution}

Apart from any consideration revealing cultural choices or privileged relationships between communities, the scale of the distribution of products manufactured on the extraction sites depends on the level of access which the communities have to the flint deposits and, as previously described, on the overall level of expertise involved in the manufacture of products (framed or not, specialised). Since the strand of the project dealing with the diffusion of mining products is still ongoing, we will confine ourselves here to a simple differentiation between diffusion within and outside the Mons Basin as listed in Table 2.

Table 2. Characterisation of extraction sites in the Mons Basin. Abbreviations: X - attested elements; U elements which remain to be defined.

\begin{tabular}{|c|c|c|c|c|c|c|c|}
\hline \multirow{2}{*}{$\begin{array}{l}\text { Sites } \\
\text { Locality }\end{array}$} & \multirow[b]{2}{*}{ Area } & \multicolumn{2}{|c|}{ Extraction method } & \multicolumn{2}{|c|}{ Productions } & \multicolumn{2}{|c|}{ Circulation } \\
\hline & & $\begin{array}{l}\text { Deep } \\
\text { pit or } \\
\text { shaft }\end{array}$ & $\begin{array}{l}\text { Dissolution } \\
\text { pipe and slope } \\
\text { structures }\end{array}$ & $\begin{array}{l}\text { Framed or } \\
\text { specialized }\end{array}$ & $\begin{array}{l}\text { Non- } \\
\text { framed }\end{array}$ & $\begin{array}{l}\text { Inside } \\
\text { the } \\
\text { Basin }\end{array}$ & $\begin{array}{c}\text { Outside } \\
\text { the } \\
\text { Basin }\end{array}$ \\
\hline $\begin{array}{c}\text { Baudour - } \\
\text { Douvrain }\end{array}$ & $\begin{array}{c}\text { Temple et } 3 \\
\text { champs }\end{array}$ & $U$ & & $\mathrm{x}$ & & $\mathrm{X}$ & $x$ \\
\hline Flénu & L'Ostenne & $x$ & & $x$ & & $x$ & $x$ \\
\hline Harmignies & La Fosse & & $x$ & $x$ & & U & \\
\hline Mesvin & Sans-Pareil & $\mathrm{X}$ & & $U$ & $U$ & $x$ & $U$ \\
\hline \multirow[t]{3}{*}{ Spiennes } & Camp-Cayaux & $x$ & & $\mathrm{X}$ & & $x$ & $x$ \\
\hline & Petit-Spiennes & $x$ & & $x$ & & $x$ & $\mathrm{X}$ \\
\hline & $\begin{array}{l}\text { Versant de la } \\
\text { Wampe }\end{array}$ & $x$ & & $U$ & & $x$ & \\
\hline Villerot & Lambiez & & $U$ & & $x$ & $x$ & \\
\hline
\end{tabular}

\subsection{Extraction sites of local importance}

\subsubsection{Harmignies La Fosse}

In 2004, workers in a chalk quarry owned by the firm CBR in Harmignies reported the discovery of an antler tool by experimental flint knappers. It was, in fact, a pick which came from a mining structure that had been cut into by the quarry face. The single extraction structure uncovered takes the form of a pit, almost $2 \mathrm{~m}$ deep, which was dug in order to exploit flint in a sub-primary position within a dissolution pipe. A flint seam in a primary position was located $50 \mathrm{~cm}$ beneath the base of the pit. AMS dating performed on three of the fifteen deer antlers associated with the exploitation level places the exploitation between 3110

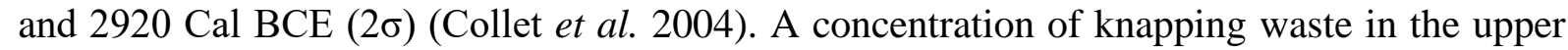
part of the back-fill is indicative of axehead and flake production. Similar remains were also found in a small pit situated $40 \mathrm{~m}$ from the extraction pit. In this case also, tool production was carried out using blocks of flint from dissolution pipe. A number of roughouts indicate a high level of expertise in bifacial manufacture.

Visual inspections of the surrounding quarry face and the scrapping of $2000 \mathrm{~m}^{2}$ failed to reveal evidence for further pits or shafts. The possibility of the feature discovered being a test pit can be discounted due to its shallow depth. The fact that flint was not extracted from the chalk itself might indicate that the activity was carried out by an individual with a poor 
knowledge of the underlying geology (Rosart 2012: 55). However, the identification of dissolution pipes from the surface and the exclusive exploitation of raw material in a subprimary position are more likely to indicate a deliberate choice. The lack of exploitation of flint from the chalk bedrock could be related to limited occupation in the area (insufficient workforce available at a given time) or limited technical skills. In fact, the exploitation of such flint would require a deeper working and would involve significant constraints (particularly in terms of ground stability). In other words, it would require much greater investment.

\subsubsection{Villerot Lambiez}

The Lambiez site at Villerot has been surveyed by Jean Dufrasnes since 2005. According to the look of nodules, the site has produced blocks of flint originating from dissolution pipes, as well as chalky blocks. In fact, there are outcrops of flint-bearing chalk in the area. The site has yielded numerous tools, interpreted as tranchets, made of local flint (probably from the Obourg chalk formation) while a very small number of artefacts, such as polished axehead fragments associated with a domestic context, are of Douvrain flint. However, a number of tools made of Villerot flint have been discovered on settlements within a $10 \mathrm{~km}$ radius (NotreDame de la Délivrance in Sirault and Rieu and L'étang de Préau in Harchies). Michel Van Assche and Jean Dufrasnes have suggested that tranchets were used as ploughing implements, not only as agricultural hoes but also as tools for the extraction of flint nodules (Van Assche \& Dufrasnes 2009). The hypothesis of limited extraction activity at Lambiez cannot be discounted, but the absence of typical mining tools and knapping areas precludes the existence of large scale extraction.

\subsection{Extraction sites of extra-regional or regional importance}

\subsubsection{Flénu L’Ostenne}

The extraction site at Flénu, on the Ostenne Plateau, was discovered in 1866 during the laying of a railway line between Mons and Dour (Hubert 1980b). Seven Neolithic extraction shafts were exposed. These shafts were sunk to exploit seams of Turonian flint at a depth of more than $10 \mathrm{~m}$ (Briart \& Cornet 1873). Immediately following the discovery, artefacts were collected by Messrs Cornet, Neyrinck, Persenaire and Piret and were deposited in the RBINS (Brussels). No excavations were carried out and the site was subsequently forgotten about for almost a century. At the end of the 1980's and the beginning of the 1990's, the site attracted the attention of a group of surveyors. With the discovery of several concentration of knapping wastes, they confirmed the mining nature of the site and also drew attention to the presence of settlements in the immediate vicinity (e.g., Flénu Les Chauffours) (Leblois \& Pacyna 1994). In addition, they highlighted the unevenness of the concentration of artefacts across the 30 to 40 hectares of the plateau compared to the Spiennes site. Our own field surveys and our study of the material held in Brussels (from imprecise origin in this area) have confirmed these observations. Apart from numerous flake cores and several thousand flakes, mention can also be made of the presence of 138 bifacial artefacts (37 polished axehead fragments, 49 axehead roughouts, 15 flint picks, 13 tranchets with the cutting edge polished and 24 undetermined items, either picks or axe roughouts). There is no evidence for the manufacture of large blades. However, it is difficult to determine precisely the origin of these Flénu pieces from the RBINS collections. Do they all come from the the mining area? According to the nature of the tools, a medley between mining site and settlement artefact is relevant. In any case, the existence of mining activity in the area is confirmed. 
The Turonian formation known as "Les Rabots" is the most represented flint-bearing formation in the Haine Valley. Considering the very hypothetical existence of a knapping workshop at St-Denis (Rutot 1911) and at Le Moulineau in Ghlin (Hubert 1980b: 432), the Ostenne site appears to be the only site that exploited Turonian flint with the aim of producing axeheads. Why is this so? The Turonian flint from the "Les Rabots" formation essentially occurs on the upper slopes of the sides of the Mons Basin. It is heterogenous in these areas. This renders it exploitable for the manufacture of small artefacts but relatively unsuitable for the mass production of axeheads and large blades. The Turonian flint of the valley sides appears to have resulted from distinct and unequal silicification episodes, probably associated with environmental changes (perhaps episodes of exondation) (personal communications with Jean-Marc Baele, Mons University, on the $4^{\text {th }}$ of October 2014). In contrast, at low altitude, as is the case in the central part of the basin and at Flénu, the environment would have been more stable. The "Les Rabots" flint is more homogenous in these areas and, therefore, more exploitable for mining.

\subsubsection{Baudour-Douvrain Temple and Trois Champs}

The flint type known as "Ghlin" flint is abundantly represented in Belgian early Neolithic collections, particularly from the Blicquian sites at the sources of the Dendre River, 10-15 km to the north of the Mons Basin (Denis 2014). The name "Ghlin flint" was coined by Marcel G. Lefrancq, member of the SRPH, who identified a block of this material within the lower part of house in the Ghlin area. He suggested a local origin for the material. The exact location of the outcrops of this flint remains unknown. Up until recently considered to have been exclusively used during the first phases of the Neolithic in Belgium, surveyors have nevertheless identified large axeheads made from this raw material in the commune of Baudour (Van Assche \& Parent 2001; Leblois 2000).

Among the Neolithic artefacts from Baudour held at the IRSNB, we have studied a group consisting of 417 axe roughouts which came from the hamlet of Douvrain (former municipality of Baudour). Acquired at the beginning of the $20^{\text {th }}$ century from a certain A. Delwarte, the acquisition records allow us to determine that they are the products of three knapping workshops. This is corroborated by their number and their remarkable state of preservation: very lightly patinated and free from plough damage. These axeheads all display a high level of skill and it is likely that they underwent a selection process within particularly well-supplied workshops.

As regards the raw material, all of the axeheads exhibit shared characteristics, pointing to a common origin which was probably local given the scale of the knapping workshops. However, they also display colour variations ranging from dull light grey to very dark bluishgrey. Certain artefacts display both colour variations. This observation, previously noted on a smaller scale (Van Assche \& Parent 2001), allows us to suggest that the "Ghlin flint" of the Blicquian series corresponds in reality to a flint facies that was later exploited for the largescale manufacture of axeheads. In fact, The "Ghlin flint" is probably of Douvrain origin as already suggested by Leblois (Leblois 2000)

Based on a shallow test excavation carried out between 1936 and 1939, Marcel G. Lefrancq suggested the existence of a mining site in the area between the Protestant church of Douvrain and a nearby street, Rue Louis Cathy (Lefrancq 1973: 58-59), close to the site of a suspected settlement at La Couture des Monts. However, an archaeological investigation carried out under the direction of Hélène Collet in 2015 in the vicinity of the Protestant church calls into question the presence of a mining site in this area. In fact, no mining feature was discovered and the investigations revealed a sandy subsoil, almost $3 \mathrm{~m}$ in depth, which would mitigate the assumption of extraction shafts in the immediate area. Nevertheless, 
occasional artefacts and nodules of Douvrain flint were discovered on the site and in back-fill material in the nearby street (Rue des Juifs), but no obvious mining product. As regards the Rue Louis Cathy, it is located on the edge of a former underground phosphate chalk working. In the absence of a known flint outcrop, the suggestion of a local origin for Douvrain-Ghlin flint seems most plausible. Flint mining picks and a fragment of antler tine were found within the lithic assemblage studied.

There is considerable variability in the morphology of axe roughouts made of Douvrain flint, a fact which prevents the tools being assigned to a precise phase of the Belgian Neolithic. While there are certain hints of exploitation during the Belgian Middle Neolithic II (Michelsberg) until the end of the Recent Neolithic from the North of France, maybe the Final Neolithic (Deûle-Escaut culture) this remains to be clarified.

\subsubsection{Spiennes Petit-Spiennes, Camp-à-Cayaux and Versant de La Wampe}

The Spiennes site, discovered in the mid- 19th century (Briart et al. 1868), has been the subject of numerous studies (Collet et al. 2008b). With 100 ha of knapping waste spread over field surfaces, and extraction structures concentrated over 40-50 ha, it is the most extensive extraction site within the Mons Basin. Archaeologists estimate the presence of between 10,000 and 20,000 shafts and a period of activity stretching between 4350 and 2300 BCE (Collet 2014). A number of open-air mines are known but most of the exploitation took the form of underground structures. They could be either 8 to $10 \mathrm{~m}$ deep, allowing the extraction of irregular nodules, or $16 \mathrm{~m}$ deep, allowing slabs of flint up to $500 \mathrm{~kg}$ in weight to be exploited (Collet et al. 2016; Hubert 1978). A recent study has shown that the selection of the raw material in the ground was determined by the type of product envisaged (Collet \& Woodbury 2007). Standardised products consist of axeheads and large blades, the latter being a unique feature in the Mons Basin. The most exceptional items were distributed over distances of more than $150 \mathrm{~km}$ from the extraction site (Catenoy Camp de César) (Bostyn \& Collet 2011). A village with an enclosure, dated to around 4000 BCE, was located in the immediate environs of the mines (Hubert 1980a) at the placed called Versant de La Wampe.

\subsection{Mesvin Sans-Pareil: An extraction site of potential regional and extra-regional importance}

In the vicinity of the destroyed and potential site of "Trous des Sarrasins" in Ciply, and within direct sight of the Spiennes site of Versant de la Wampe (1.2 km away), lies the site of Sans-Pareil in Mesvin. This area was previously extensively prospected for its underlying phosphate chalk deposits. In the 1880's, a mining director, Alfred Lemonnier, discovered a series of red deer antlers and polished bone tools. The presence of inclusions and evidence for use-wear indicate that these were extraction tools (Hauzeur 2011). The SRPH conducted a rescue excavation in the area in 1957 that revealed a group of five Neolithic extraction pits, only one of which was excavated (Lefrancq \& Moisin 1965). It took the form of a shaft, with a diameter of $4.2 \mathrm{~m}$ and a depth of $4 \mathrm{~m}$, which provided access to three galleries. A single flint seam within the Spiennes chalk was exploited. Very little lithic material was discovered. Worth noting, however, was the presence of crude multi-face picks along with antler and cattle bone tools. Three radiocarbon dates have been realized (two on oaks, one on antler tool), providing a date around 4000 BCE, but with a large standard deviation. In 2006, Hélène Collet carried out an archaeological investigation in advance of construction work. An extraction pit, completely devoid of lithic material, was revealed. To this day, the Mesvin site remains poorly understood. Additional survey work would help in determining its extent and would throw light on the products associated with its operation. 


\section{Discussion}

From our initial corpus of eleven sites, six have been identified as extraction sites. These are characterised on the basis of the sophistication of the extraction methods used, the nature of the products produced and by the distribution of these products. A hierarchy of extraction sites emerges, similar to that revealed for the North of France (Bostyn 2008). Two trends can be identified, corresponding to different acquisition-production strategies or, in other words, to distinct roles within the socio-economic organisation of Neolithic populations. Mining sites have various aims.

There is clear variation in the products of various extraction sites such as Villerot Lambiez and Harmignies: framed at Harmignies, non-standardised at Villerot). However, they are both characterised by limited investment in the acquisition of flint. The accessibility of the raw material justifies the extraction but the modus operandi, which is opportunistic, is not reproducible on a large scale (exploitation of dissolution pipes). Consequently, their economic impact remains local, as our current research will confirm.

The extraction sites of Spiennes, Douvrain, Flénu and Mesvin can be differentiated from each other by a very uneven presence of their products within the lithic assemblages. Nonetheless, they are characterised by significant investment in the acquisition of the raw material, which allowed the obtainment, on a recurrent basis, of specific forms of blanks (nodules greater than $20 \mathrm{~cm}$ and slabs weighing several hundred kilos) required for the manufacture of framed or specialised products (regular blades and axeheads). The homogeneity and mastery of the approaches employed over several centuries in the extraction-production process would seem to suggest that mining activities were carried out, or at least managed, by the local populations. The presence of a village with miners is attested at Spiennes Versant de La Wampe and habitation sites are suspected to exist in close proximity to the mining sites of Douvrain (i.e. La Couture des Monts) and Flénu (i.e. Les Chauffours). However, the importance of these sites goes well beyond the context of the Basin. An axe of Douvrain flint, for example, has recently been discovered at Baisieux in the Escaut Valley (Gillet et al. 2015), a distance of $45 \mathrm{~km}$ from the extraction site, while Turonian flint from Flénu represents up to $30 \%$ of the assemblages from habitation sites in the Nivelles region (Hubert 1982). In the case of Spiennes flint, while the raw material, in the form of blocks, is imported to habitation sites within a $15 \mathrm{~km}$ radius of the source, its specialised products, blades and axes, are distributed over distances of up to $150 \mathrm{~km}$ (Bostyn \& Collet 2011). These mining sites guaranteed supply both to local communities and to populations living far from the flint sources, essentially through the distribution of their framed or specialised products. As the driving force within a raw material economy, on a regional and extra-regional scale (Perlès 1991), they play a key structural role within socioeconomic organisation.

\section{Conclusion and perspectives}

A clearer picture of flint acquisition sites in the Mons Basin is emerging. A correlation can be established between significant investment in the extraction method and a structural economic role, a fact which distinguishes the main mining sites from other extraction sites. Further clarification is needed, particularly from a diachronic point of view and also regarding extra-regional distribution networks. To this end, we are turning our attention towards the distribution of the products from the mining sites of Spiennes, Flénu and Douvrain. Existing literature and our preliminary results suggest that these sites are partially contemporaneous. The diffusion of different raw materials and products on the same settlement from close mining sites also prompts the question of a possible form of organisation, or even specialisation (a framed production of blades is only attested at Spiennes) within the 
extraction sites of the Mons Basin. If this hypothesis is confirmed, we hope to be able to compare the Mons Basin mines with other groups such as the mines of the Pays d'Othe or those of the Netherlands.

\section{Acknowledgements}

I wish to thank the F.R.S-FNRS for financing this doctoral research. I also wish to express my warm gratitude to Ivan Jadin who provided me with access to, and guided me around, the collections of the IRSB and who provided valuable archival information. Thanks also to Jean Dufrasnes and Michel Van Assche who introduced me to the Villerot site and who gave me the opportunity to study the finds from the site. Thanks to Françoise Bostyn and Hélène Collet for fruitful discussions as well as both reviewers. Thanks also to Rhoda Allanic and to the LIATEC Laboratory at UNamur for their work on the translation. Finally, I wish to express my gratitude to Laurence Burnez-Lanotte for her support and guidance throughout the writing of this article.

\section{References}

Allard, P., Bostyn, F. \& Fabre, J. 2005, Origine et circulation du silex durant le Néolithique en Picardie. Des premières approches ponctuelles à une systématique régionale. Revue Archéologique de Picardie, 22: 49-74. (in French) (“Origin and circulation of flint during the Neolithic in Picardy. From firsts and punctual approaches to a regional system”) doi:10.3406/pica.2005.2721

Allard, P., Hamon, C. \& Sidera, I. 2006, Investissement technique et degrés d'élaboration des productions lithiques et osseuses du Rubané dans le Bassin Parisien. In: Normes techniques et pratiques sociales de la simplicité des outillages pré- et protohistoriques: Actes des [XXVIe] Rencontres internationales d'Archéologie et d'Histoire d'Antibes, 2022 octobre 2005 (Astruc, L., Bon, F., Léa, V., Milcent, P.-Y. \& Philibert, S., Eds.), Association pour la promotion et la diffusion des connaissances archéologiques, Antibes: p. 175-194. (in French) ("Technical investment and degrees of development of the lithic and osseous production in the Linear Pottery Culture from the Paris Basin”) URL : http://www.mae.u-paris10.fr/prehistoire/IMG/pdf/CL-CL-2006-Allard.pdf

Van Assche, M. \& Parent, S. 2001, Regard sur un ensemble de sites préhistoriques à Harchies (Bernissart, Hainaut). Vie Archéologique, 69: 5-25. (in French) (“A look at a cluster of prehistoric sites in Harchies (Bernissart, Hainaut)”)

Van Assche, M. \& Dufrasnes, J. 2009, Villerot: Une exploitation de silex au Néolithique. L'Archéologie en Hainaut Occidental, 8 : 22-24. (in French) ("Villerot: A Neolithic flint exploitation")

Bostyn, F. 2008, Produire pour soi ou produire pour les autres: Rôle des mines et carrières dans l'organisation socio-économique néolithique. Archéopages, 22: 6-13. (in French) ("Produce for oneself or produce for others: Role of mines and quarries in Neolithic socio-economic organization”) URL: http://dolia.inrap.fr/flora/ark:/12345/0139332

Bostyn, F. \& Collet, H. 2011, Diffusion du silex de Spiennes et du silex Bartonien du Bassin parisien dans le Nord de la France et en Belgique de la fin du 5e millénaire au début du 4e millénaire BC: Une première approche. Revue Archéologique de Picardie. (Le Néolithique du Nord de la France dans son contexte européen: Habitat et économie aux 4e et 3e millénaires avant notre ère) (Bostyn, F., Martial, E. \& Praud, I., Eds.), 28 (special issue): 331-347. (in French) ("Diffusion of Spiennes flint and Bartonian flint 
from the Paris Basin in the North of France and Belgium: A first approach”) doi:10.3406/pica.2011.33399

Briart, A., Cornet, F. \& Houzeau de Lehaie, A. 1868, Rapport sur les découvertes géologiques et archéologiques faites à Spiennes en 1867. Mémoires et publications de la Société des Sciences, des Arts et des Lettres du Hainaut (année 1866-1867), 3(2): 355-398. (in French) ("Report on the geological and archaeological discoveries made at Spiennes in 1867”)

Briart, A. \& Cornet, F.L. 1873, Sur l'Age de la pierre polie et les exploitations préhistoriques de silex dans la province de Hainaut. In: Congrès international d'anthropologie et d'archéologie préhistorique. Compte rendu $6^{e}$ session, C. Muquardt, Paris: p. 219-299. (in French) ("About the Age of the polished stone and the prehistoric exploitations of flint in the province of Hainaut”)

Collet, H., Collette, O. \& Woodbury, M. 2004, Indices d'extraction et de taille du silex datant du Néolithique récent dans la Carrière CBR à Harmignies. Notes préliminaires. Notae Praehistoricae, 24: 151-158. (in French) ("Indices of extraction and knapping of flint dating from the recent Neolithic in the CBR Quarry at Harmignies. Preliminary notes") URL: http://www.naturalsciences.be/mars/groups/fnrs-contact-group/notaepraehistoricae/notae-praehistoricae-24-2004

Collet, H. \& Woodbury, M. 2007b, Etude et caractérisation des déchets lithiques abandonnés dans les niveaux d'exploitation de la minière ST 20 de Petit-Spiennes (Province de Hainaut). Notae Praehistoricae, 27: 151-122. (in French) ("Study and characterisation of the flint waste abandoned in the mining levels of ST 20 shaft at Petit-Spiennes (Hainaut Province)”) URL: http://www.naturalsciences.be/mars/groups/fnrs-contactgroup/notae-praehistoricae/notae-praehistoricae-27-2007

Collet, H., Jadin, I. \& Woodbury, M. 2008a, Apport à la chronologie absolue des minières néolithiques de Spiennes. Notae Praehistoricae, 28: 97-99. (in French) (“Contribution to the absolute chronology of the Neolithic mines of Spiennes")

URL: http://www.naturalsciences.be/mars/groups/fnrs-contact-group/notaepraehistoricae/notae-praehistoricae-28-2008

Collet, H., Hauzeur, A. \& Lech, J. 2008, The prehistoric flint mining complex at Spiennes (Belgium) on the occasion of its discovery 140 years ago. In: Flint mining in Prehistoric Europe: Interpreting the archaeological records (Allard, P., Bostyn, F., Giligny, F. \& Lech, J., Eds.), European Association of Archaeologists, 12th Annual Meeting, Cracow, Poland, 19th-24th September 2006, British Archaeological Reports (BAR) International Series Vol. 1891. Archaeopress, Oxford: p. 41-77.

URL: http://minesdespiennes.org/textes/Collet_Hauzeur_Lech2008.pdf

Collet, H. 2014, Les minières néolithiques de silex de Spiennes : Patrimoine mondial de l'Humanité. Carnets du Patrimoine Vol. 126. Institut du Patrimoine Wallon, Namur, 55 p. (in French) ("The Neolithic flint mines of Spiennes. A world heritage site")

Collet, H., Woodbury, M. \& Collin, J.-Ph. 2014, Investigation of new chipping floors at the flint mining site of Spiennes (Hainaut Province, Belgium) in 2011 and 2012. In: Lithic raw Material Resources and Procurement in Pre- and Protohistoric Times: Proceedings of the $5^{\text {th }}$ International Conference of the UISPP Commission on Flint Mining in Pre- and Protohistoric Times, Paris 10-11 September 2012 (Bostyn, F. \& Giligny, F., Eds.), British Archaeological Reports International Series Vol. 2656, Archaeopress, Oxford: p. 47-58. 
Collin, J.P. 2010, Étude des outils miniers de la structure d'extraction néolithique "ST 20" de Petit-Spiennes, Spiennes (Hainaut, Belgique): Approche morphologique, technologique et fonctionnelle. Unpublished Master Thesis, Université Libre de Bruxelles, Brusselles, 100 p. (in French) ("Study of the mining tools of the Neolithic extraction structure "ST 20” of Petit-Spiennes, Spiennes (Hainaut, Belgium): Morphological, technological and functional approach")

Collin, J.P. \& Collet. H. 2011, Mode d'acquisition, stigmates d'utilisation et motifs d'abandon des outils d'extraction du puits néolithique "ST 20" de Petit-Spiennes, Spiennes (Hainaut, Belgique). Anthropologica et Praehistorica, 122: 1-56. (in French) ("Mode of acquisition, usewear and reasons for abandonment of the tools from the neolithic extraction shaft "ST20” of Petit-Spiennes, Spiennes (Hainaut, Belgium)”)

Collin, J.P. \& Collet, H. (2012), La Lithothèque du Bassin de Mons: Un projet de géoarchéologie. Oral presentation presented at the Journée du Groupe de Contact FNRS (2012), Bruges, $8^{\text {th }}$ of December 2012. (in French) ("The Mons Basin Lithothèque: A geoarchaeology project”)

Collin, J.P. \& Baele, J.M. (2016), Macro-, meso- and microscopic scale characterization of Cretaceous flints from the Mons Basin (Belgium). New data for Neolithic mining sites. Poster presented at the European Association of Archaeologists meeting (2016), Vilnius, 1st of September 2016.

Constantin, C. 1985, Fin du Rubané, céramique du Limbourg et post-Rubané. Le Néolithique le plus ancien en Bassin parisien et en Hainaut. BAR International Series Vol. 273, British Archaeological Reports, Oxford, 2 vol., 356 p. (in French) ("End of the Linear Pottery Culture, Limburg and post-Linear Pottery Culture ceramics. The oldest Neolithic in the Paris Basin and in Hainaut”) doi:10.1017/s0079497x00006836

Cornet, E. 1947, Sites et découvertes de Ciply (Hainaut). Vue d'ensemble. In: Mélanges d'histoire offerts à Léon van der Essen à l'occasion de sa trente-cinquième année d'enseignement à l'Université de Louvain, Vol. 1 (Willaert, R.P.L., Scheerder, J., Eds.), Éditions universitaires, Bruxelles: p. $42-56$ (in French) ("Sites and discoveries In Ciply (Hainaut). Overview”)

Denis, S. 2014, The circulation of Ghlin flint during the time of the Blicquy-Villeneuve-SaintGermain culture (Early Neolithic). Journal of Lithic Studies, 1(1): 85-102. doi:10.2218/jls.v1i1.780

Gillet, E., Martial, E., Praud, I. with the collaboration of Bardel, D. \& Deschodt, L. 2015, Baisieux, rue de la Malterie (Nord). Occupations néolithique et protohistorique. Unpublished survey report for the INRAP Nord-Picardie, on file, INRAP, NordPicardie, 96 p. (in French) ("Baisieux, rue de la Malterie (North Department). Neolithic and protohistoric occupations”)

Gosseries, A. 1908, Monographie du village de Ciply, Dequesne-Masquillier et Fils, Mons, 165 p. (in French) ("Monograph of the village of Ciply")

Hauzeur, A. 2011, Extraction et terrassement à Mesvin - «Sans Pareil» (Hainaut, Belgique). Outils miniers en matière dure animale de la collection Lemonnier (IRScNB). Anthropologica et Praehistorica, 122: 87-106. (in French) ("Extraction and earthworks at Mesvin - "Sans Pareil" (Hainaut, Belgium). Osseous mining tools from the Lemonnier collection (RBINS)”) 
Heinzelin, J. de, Orban, R., Roels, D. \& Hurt V. 1993 , Ossements humains dits néolithiques de la région de Mons (Belgique), une évaluation. Bulletin de l'Institut Royal des Sciences Naturelles de Belgique, Sciences de la Terre, 63: 311-336. (in French) ("Socalled Neolithic human bones from the Mons region (Belgium), an evaluation”)

Hubert, F. 1970, Ellignies-Ste-Anne (Ht.): Un site de la civilisation Roessen. Archéologie, 1: 17-21. (in French) (“Ellignies-Ste-Anne (Ht.): A site of the Roessen civilization”)

Hubert, F. \& Lefrancq, M.G. 1973, Obourg - minières néolithiques. In: Archéologie de la région de Mons, catalogue d'exposition Maison de la Culture de Mons, Ministère de la Culture Française, Brussels: p. 57-58. (in French) (“Obourg - Neolithic mines”)

Hubert, F. 1978, Une minière néolithique à silex au Camp-à-Cayaux de Spiennes. Archaeologia Belgica Vol. 210, Service national des Fouilles, Brussels, 42 p. (in French) (“A Neolithic flint mine at Camp-à-Cayaux in Spiennes”)

Hubert, F. 1980a, Le camp Michesberg de Spiennes. Archaeologica Belgica, 223: 35-38. URL: http://www.minesdespiennes.org/blog/wp-content/uploads/2013/02/Hubert1978_AB-210.pdf

Hubert, F. 1980b, Silexabbau und -gewinnung in Belgien. In: 5000 Jahre Feuersteinbergbau (Weisgerber, G., Slotta, R. \& Weiner J., Ed.), Deutsches Bergbau-Museum Bochum, Bochum: p. 412-433. Bochum. (in German) (“Mining and flint extraction in Belgium”)

Hubert, F. 1982, L'habitat néolithique dans la région de Nivelles. Annales de la société d'archéologie, d'histoire et de folklore de Nivelles et du Brabant wallon, 24: 8-36. (in French) ("Neolithic settlement in the Nivelles region")

Jadin, I., Collet H., Woodbury, M. \& Letor, A. 2008, Indices d'extraction néolithique à Obourg - Le Village. Notae Praehistoricae, 28: 93-96. (in French) (“Neolithic mining evidence at Obourg - Le Village”)

URL: http://www.naturalsciences.be/mars/groups/fnrs-contact-group/notaepraehistoricae/notae-praehistoricae-28-2008

de Labriffe, P.-A. \& Thirault, E. (Eds.) 2012, Produire des haches au Néolithique. De la matière première à l'abandon, Actes de la Table ronde de Saint-Germain-en-Laye, 1617 mars 2007, Musée des Antiquités nationales. Séances de la Société Préhistorique Française Vol. 1, Société Préhistorique Française, Paris, 247 p. (in French) ("Produce axes in the Neolithic. From raw material to abandonment”) URL: http://www.prehistoire.org/515_p_31398/sommaire-seance-1.html

Leblois, E. \& Pacyna, D. 1994, Cuesmes, notes d'archéologie préhistorique, protohistorique, gallo-romaine et mérovingienne. Annales du Cercle Archéologique de Mons, 76: 3-72. (in French) ("Cuesmes, notes of prehistoric, protohistoric, Gallo-Roman and Merovingian archeology")

URL: https://www.rechercheisidore.fr/search/resource/?uri=10670/1.slgjp4

Leblois, E. 2000, Bilan de cent cinquante années de découvertes archéologiques à Baudour. Première partie: Fouilles, découvertes fortuites et prospections. Annales du Cercle d'Histoire et d'Archéologie de Saint-Ghislain et de la Région, 8: 127-242. (in French) ("Results of one hundred and fifty years of archaeological discoveries in Baudour. Part 1: Excavations, fortuitous discoveries and prospecting”)

Lefrancq, M.G. \& Moisin, P.H. 1965, Le Néolithique ancien en Belgique: Datation au 14C (Lv-65 et -216) de la minière de Mesvin «Sans Pareil», Hainaut. Mémoires et Publications de la Société des Sciences, des Arts et des Lettres du Hainaut, 79: 405-429. 
(in French) ("The Early Neolithic in Belgium: Dating at 14C (Lv-65 and -216) of the mine of Mesvin “Sans Pareil””) URL: http://www.persee.fr/doc/rnord_00352624_1969_num_51_202_5909_t1_0557_0000_2

Lefrancq, M.G. 1973, Douvrain: exploitation de silex. In: Archéologie de la région de Mons, catalogue d'exposition Maison de la Culture de Mons, Ministère de la Culture Française, Brussels: p. 58-59. (in French) (“Douvrain: Flint exploitation”)

Moreau, L., Brandl, M., Filzmoser, P., Hauzenberger, C., Goemaere, É., Jadin, I., Collet, H., Hauzeur, A. and Schmitz, R. W. 2016, Geochemical Sourcing of Flint Artifacts from Western Belgium and the German Rhineland: Testing Hypotheses on Gravettian Period Mobility and Raw Material Economy. Geoarchaeology, 31: 229-243. doi:10.1002/gea.21564

Mortier, T. (Ed.) 2012, Itinéraire pédagogique du géoparc du Bassin de Mons, Vol. 1: Introduction générale à la géologie, A.S.B.L. Malogne

, Mons, 77 p. (in French) ("Educational itinerary of the Mons Basin geopark, Vol. 1: General introduction to geology")

de Munck, E. 1928, Enquêtes sur la distribution géographique du silex du Grand-Pressigny (Indre-et-Loire). Bulletin de la Société d'Anthropologie et de Préhistoire, 43: 76-79. (in French) ("Investigations on the geographical distribution of flint of the Grand Pressigny (Indre-et-Loire)”)

de Munck, E. 1929, Notes sur la nature de certains silex des stations néolithiques de SaintSymphorien (Hainaut) et des silex originaires du Grand-Pressigny (Indre-et-Loire). Bulletin de la Société d'Anthropologie et de Préhistoire, 44: 115-117. (in French) ("Notes on the nature of some flints of the neolithic stations of Saint-Symphorien (Hainaut) and flints from Grand Pressigny (Indre-et-Loire)”)

Pelegrin, J. 1991, Les savoir-faire: Une très longue histoire. Terrain, 16: 106-113. (in French) ("Know-how: A long history ") doi:10.4000/terrain.3001

Pelegrin J. \& Richard, A. (Eds.) 1995, Les mines de silex au Néolithique en Europe. Avancées récentes. Actes de la table-ronde internationale de Vesoul, Comité des travaux historiques et scientifiques, Paris, 288 p. (in French) ("Flint mines in the Neolithic in Europe. Recent advances”)

Pelegrin, J. 2007, Réflexions sur la notion de "spécialiste” dans la taille de la pierre au Paléolithique. Documents Préhistoriques, 24: 315-318. (in French) ("Reflections on the notion of "specialist" of stone knapping at the Palaeolithic") URL: http://www.mae.uparis10.fr/prehistoire/IMG/pdf/JP-specialistes.pdf

Rosart, A. 2012, Étude d'une structure d'extraction de silex trouvée dans la carrière CBR à Harmignies (Province de Hainaut) et du mobilier s'y rapportant. Unpublished Master Thesis, Université Catholique de Louvain, Louvain-la-Neuve, 153 p. (in French) ("Study of a flint extraction structure in the CBR quarry in Harmignies (Province of Hainaut) and related artefacts”)

Perlès, C. 1991, Économie des matières premières et économie du débitage: Deux conceptions opposées? In: 25 ans d'études technologiques en Préhistoire: Bilan et perspectives. Actes des rencontres 18-19-20 oct. 1990, Juan-les-pins. Éditions Association pour la promotion et la diffusion des connaissances archéologiques (APDCA), Antibes, p. 35-45. (in French) ("Economy of raw materials and economy of debitage: Two opposed conceptions?”) 
Rutot, A. 1911, À propos de l'enquête sur la dispersion des silex du Grand Pressigny. In: Congrès préhistorique de France, $6^{e}$ session. Tours 1910 (1911), Société Préhistorique Française, Paris: p. 301-308. (in French) (“About the Grand Pressigny flint dispersion investigation")

Weisgerber, G., Slotta, R. \& Weiner J. (Eds.) 1980, 5000 Jahre Feuersteinbergbau, Deutsches Bergbau-Museum Bochum, Bochum, 672 p. (in German) ("5000 years of flint mining”) 